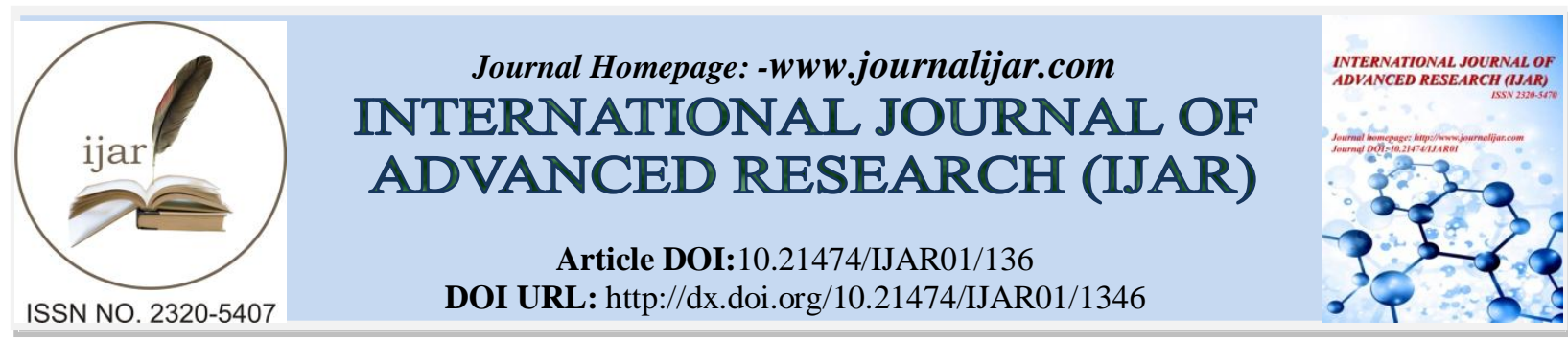

RESEARCH ARTICLE

\title{
INFLUENCE OF GENETIC AND NON-GENETIC FACTORS ON THE GROWTH PERFORMANCE OFDWARF SHEEP OF DJALLONKE BREED REARED ON NATURAL PASTURE IN BENIN.
}

\author{
Adjibode G. ${ }^{1}$, Tougan U.P. ${ }^{2,4}$, Daouda I-H. ${ }^{2}$, Boko K.C. ${ }^{1}$, Mensah G.A. ${ }^{3}$, Youssao A.K.I. ${ }^{1}$, Hanzen Ch., Thewis
} A. ${ }^{4}$ andKoutinhouin G.B. ${ }^{1}$

1. Department of Animal Production and Health, Polytechnic School of Abomey-Calavi, 01 BP 2009, Cotonou, Republic of Benin, Benin.

2. National High School of Agro-Pastoralism (ENSAP-Gogounou), University of Parakou, Republic of Benin.

3. Agricultural Research Center of Agonkanmey, National Institute of Agricultural Research of Benin, 01 BP 884, Cotonou 01, Republic of Benin.

4. Animal Sciences Unit, Gembloux Agro-Bio Tech, University of Liege, Passage des Déportés, 2, 5030 Gembloux, Belgium.

\section{Manuscript Info}

Manuscript History

Received: 12 June 2016

Final Accepted: 14 July 2016

Published: August 2016

Key words:-

Weight, Djallonke sheep, growth, ecotype, average daily gain, variability.

\section{Abstract}

Thestudy aims to determine the variability of growth performancein Djallonkedwarf sheep reared on natural pasture in Benin according to the ecotype, sex, season, lambing rank and litter size. Data were then collected on 1061 sheep including 462 ofNorth ecotype and 599 ofSouth ecotype, from November 2014 to December 2015. These data were analyzed with SAS software (2006). The obtained results show that the sheep ecotype had affected $(p<0.05)$ the different age-type weights and Average daily gain excluding the birth weight, weights at 270, 315, 330, 345 and 360 days. Animals of North ecotype were overall heavier than those of South ecotype. Except the birth weight, the sex had influenced the age-type weight of sheep with males heavier than females $(p<0.05)$. The season didn't influence age-type weights excluding the weight at 120 days. However, the average daily gains were affected $(\mathrm{p}<0.05)$ by season excluding the values recorded from the age of 120 to 240 days with higher ADG found in animal born during the dry season. The lambing rank had only affected the weight at 225 days, 240 days and 255 days $(\mathrm{p}<0.05)$ with the lesser growth found in animal born at the first lambing.Except the weights recorded from the birth to the age of 120 days and the live weights at 195, 210 and 225 days, the litter size didn't affected the others growth parameters. Non-genetic factors involved in this study must be taken into account to improve Djallonkesheep production in Benin.

Copy Right, IJAR, 2016,. All rights reserved.

\section{Introduction:-}

The current greatest challenge of the West African countries is food security and safety, and consists on obtaining and guaranteeing an increasing food production of best quality for the population which increase year by year (FAOSTAT, 2010). In the sector of animal production, small ruminant breeding in general and dwarf sheep rearing

Corresponding Author:-Tougan U.P.

Address: National High School of Agro-Pastoralism (ENSAP-Gogounou), University of Parakou, 
in particular represents one of the ways on which sub-Saharan Africa countries were committed to increase their production of animal proteins.

The small ruminantproduction in general and sheep rearingin particular is a widespread activity in Benin, as in most countries in sub-Saharan Africa (Gbangboché et al., 2005a, SWAC-OECD / ECOWAS 2008;Babatunde et al, 2010). Due to its relative simplicity compared to the rearing of large animals (Vallerand and Blanckaertr, 1975; London and Weninger, 1996), sheep rearing become widespread over the years with a national herd increasing from 690,000 heads in 2003 to 860,000 heads in 2013 (CountyStat, 2016). Its importance in social terms is well known because it is a source of income for households and its productsare used in several occasions and religious events (Tabaski, sacrifice, etc.) or social (marriage, baptism gifts , dowry, burial, ...) (Bamikolé et al., 2001; CTA, 2006; Boudisatria et al., 2010, Adjibode, 2012; Lalit et al, 2016).

Djallonke sheep is the most reared sheep breed in Benin (Gbangboche et al., 2004) because of its perfect adaptation to the local climatic conditions and its resistance (Mawuena 1987; Gbangboché et al., 2005a,Gbangboché at al., 2005b).

This West African Dwarf sheep is a hairy sheep breed found all over West and Central Africa south of $14^{\circ}$ latitude, and widely distributed throughout 12 the savannah and humid zones. The characteristics of WAD sheep have been described by severalauthors (Rombaut et Van Vlaenderen, 1976;Pagot, 1985 ;Larrat, 1989; Fournier, 2006; Gbangboché et al., 2005). It is a compact breed with a small mature size and short horizontal lopears. Coat colour varies from spotted black and white to solid black or white. Some have tan or brown coat colour and black bellies. Rams are horned and females usually polled. WAD sheep are capable of limiting parasite multiplication andremain productive in tsetse-infested areas where other breeds can't survive without treatment(Ayuket al., 2014).

The dwarf sheep is reared in Benin mainly according to traditional rearing system and met alone or generally associated with other animal species in almost all households. However, West African dwarf sheep have low productivity (Yapi, 1994) and weak reproduction and growth performance (Adjibodè, 2012) varying with latitude from north to the south of Benin (Gbangboché et al., 2005b; Youssao et al., 2008).

Few studies (Gbangboché et al., 2004; Akouedegni et al., 2013; Awohouedji et al., 2013) are carried on the characterization of Djallonke sheep reared in Benin. Furtheremore, these studies are conducted in station where farming is of semi-modern type (Gbangboché et al., 2004; Akouedegni et al., 2013; Awohouedji et al., 2013). The various data on growth and reproductive performancesin Djallonke sheep of Benin are provided by studies focused mostly the fields offeeding and animal health (Hounzangbe-Adote et al., 2001; Aboh et al., 2008; Babatunde et al., 2008; Babatunde et al., 2009; Awohouedji et al, 2013, DokoAllou et al., 2013).

The development of this animal breeding sector and the importance of the consumption of the dwarf sheep meat nowadays in West Africa in general and in Benin in particular require a better knowledge, control and improvement of its rearing system, reproductive and growth performance.

According to Berhanu and Aynalem (2009), growth performance is a key production indicator that has implications in the reproductive efficiency of sheep. Fast growth performance allows sheep to breed early and contribute more lambs in their lifetime. Fast growth rate entails reaching market weight early and brings a quicker income to the farmer.

The effect of non-genetic factors on growth performance in sheep has been investigated in several studies. These factors in different areas have their own specific effects regarding the environmental characteristics of related areas (Gbangboche et al., 2006; Momoh et al., 2013). Therefore, the present study was carried out to investigate the effect of ecotype, sex of lamb, season of birth and litter size on growth performance ofDjallonkelambs at different ages reread undertraditional system in Benin.

Specifically, it is to:

- Compare the growth performance of Djallonkelambs of North and south ecotypes reared under village traditional management conditions;

- Quantify the impact of sex, season of birth and litter size and lambing rank on growth performance in Djallonke lambs. 


\section{Material and methods:- Studyarea:-}

The study was carried to investigate the growth performance of Djallonke lambs of North and South ecotypes of Benin reared under village management conditions. The study was thus conducted conjointly at the North and the South of Benin respectively in the departments Atlantic and Borgou. Situated between the latitudes of $6^{\circ} 20^{\prime}$ and $12^{\circ} 30^{\prime}$ 'north and between the longitudes of $1^{\circ} 30^{\prime}$ and $3^{\circ} 45$ East, the republic of Benin covers an area of $113440 \mathrm{~km}^{2}$ with a population of 10448647 inhabitants(INSAE, 2015) and a density of60 hab./km².

The department Atlantic exhibits climatic conditions of sub-equatorial type, characterized by two rainy seasons with an uneven spatial and temporal distribution of rainfall: major (from April to July) and minor (from September to November). These two seasons are separated by a dry season. Average rainfall is close to $1200 \mathrm{~mm}$ per year. The monthly average temperatures vary between 27 and $31^{\circ} \mathrm{C}$ and the relative air humidity fluctuates between $65 \%$, from January to March, and 97\%, from June to July.

The department Borgou exhibits climatic conditions of Sudan type, characterized by only one rainy season (from April to October) and one dry season (November to March). Average rainfall varies between 900 and $1300 \mathrm{~mm}$ per year while the average annual temperature is $26^{\circ} \mathrm{C}$ with a maximum of $32^{\circ} \mathrm{C}$ in March and a minimum of $23^{\circ} \mathrm{C}$ from December to January. The relative humidity varies between 30 and $70 \%$. Vegetation of Borgou department is a diversified savannah where tree density decreases towards the North.

\section{Data collection:-}

Data were collected from November 2013 to December 2015 on a total of 1061 dwarf sheep ofDjallonke breed including 462 of North ecotype and 599 ofSouth ecotype. These animalswere all raised in a traditional system. Feeding was mainly based on natural pasture. The animals were put on pasture at about 7.30 a.m. and returned to the barns in the afternoon. They were then fed ad libitum a supplementary diet consisting of crop residues acording to the traditional system.

The sheep were treated for ectoparasites, drenched once every three months and given other veterinary attention when the need appeared.

The material used for data collectionwas composed of a growth data file for recording the growth parameters and electronic balancesof $5 \mathrm{~kg}$ and $40 \mathrm{~kg}$ of capability and accuracy of $1 \mathrm{~g}$ and $20 \mathrm{~g}$ respectively. The data file contained information on individuals, identification code, sex, litter size, birth date, date of weighing and measure of body weight.

The birth weight (W0) of lambs wasrecorded and the animals were then weighed once every fourteen days up to 12 months of age. Average daily gainswere calculated from the birth to the age of 120 days, from the age of 120 days to the age of 240 days and from the birth to the age of 240 days.

\section{Statistical analysis:-}

Records of the birthweight, age-type live weights, litter birthweight, litter size at birth, litter size at weaning and average daily gain (ADG)were analyzed for the effects of ecotype (North and South), season of birth (dry season; rainy season), type of birth, litter composition and sex using the software Statistical Analysis System (SAS, 2006). For the analysis of variance, a fixed linear model was adjusted to the productivity and the growth data. This model includes the fixed effects of genetic type, season of birth, lambing rank, litter size and sex. The F test was used to determine the significance of each effect in the model. Means were compared two by two by the Student's t test.

\section{Results:-}

Variation of age-type weight and average daily gain (ADG) of Djallonke sheep of Benin according to the ecotype:-

The effect of ecotype on the growth performances of dwarf lambs of Djallonke breed is given in table 1.The birth weight was similar for both ecotypes (North and South; $p>0.05$ ). It was of $2.01 \pm 0.03 \mathrm{~kg}$ for lambs ofNorth ecotype and $2.07 \pm 0.03 \mathrm{~kg}$ for South ecotype. From the birth to the age of 250 days, the different age-type weights were all affected by the ecotype of lamb with the best values recorded in the animals of North ecotype $(\mathrm{p}<0.05)$. Similarly, 
the live weight of the lambs of North ecotype at 285 days old was higher than the one recorded in South ecotype $(\mathrm{p}<0.05)$. However, the ecotype didn't affect the live weights of the lambs at 270 and 300days old.

Table 1:- Variation of age-type weight and average daily gain (ADG) according to the ecotype.

\begin{tabular}{|c|c|c|c|c|c|}
\hline \multirow[t]{2}{*}{ Variables } & \multicolumn{2}{|c|}{ North $(N=462)$} & \multicolumn{2}{|c|}{ South $(N=599)$} & \multirow[t]{2}{*}{ ANOVA } \\
\hline & Mean & Standard error & Mean & Standard error & \\
\hline W0 & 2.01 & 0.03 & 2.07 & 0.03 & NS \\
\hline W15 & 3.50 & 0.05 & 3.29 & 0.05 & *** \\
\hline W30 & 4.72 & 0.06 & 4.26 & 0.07 & $* * *$ \\
\hline W45 & 5.98 & 0.09 & 5.24 & 0.08 & $* * *$ \\
\hline W60 & 7.14 & 0.11 & 6.24 & 1.42 & *** \\
\hline W75 & 8.21 & 0.18 & 7.15 & 0.14 & $* * *$ \\
\hline W90 & 9.41 & 0.22 & 8.04 & 0.16 & $* * *$ \\
\hline W105 & 10.54 & 0.22 & 8.86 & 0.20 & $* * *$ \\
\hline W120 & 11.46 & 0.26 & 9.74 & 0.23 & $* * *$ \\
\hline W135 & 12.41 & 0.29 & 10.38 & 0.23 & $* * *$ \\
\hline W150 & 13.37 & 0.33 & 11.11 & 0.23 & *** \\
\hline W165 & 14.02 & 0.37 & 14.46 & 0.26 & $* * *$ \\
\hline W180 & 14.77 & 0.48 & 11.95 & 0.31 & $* * *$ \\
\hline W195 & 15.13 & 0.54 & 12.23 & 0.37 & $* * *$ \\
\hline W210 & 15.38 & 0.58 & 13.29 & 0.38 & $* * *$ \\
\hline W225 & 15.97 & 0.62 & 13.94 & 0.46 & *** \\
\hline W240 & 16.45 & 0.79 & 14.37 & 0.62 & $* * *$ \\
\hline W255 & 16.81 & 1.59 & 14.97 & 0.66 & $* *$ \\
\hline W270 & 16.97 & 1.42 & 15.85 & 1.40 & NS \\
\hline W285 & 17.56 & 1.64 & 16.22 & 1.08 & * \\
\hline W300 & 17.73 & 1.84 & 16.96 & 1.50 & NS \\
\hline ADG0_120 & 79.48 & 1.76 & 62.15 & 2.31 & $* * *$ \\
\hline ADG20_240 & 59.72 & 2.49 & 51.45 & 1.87 & $* *$ \\
\hline ADG120_240 & 50.58 & 4.11 & 40.01 & 2.47 & * \\
\hline
\end{tabular}

Wi: Live weight at I days old; ADG i_j: Average Daily gain calculated from I days to j days old; N: Number; SE: Standard Error, ANOVA: Analysis of Variance, *: $\mathrm{P}<0.05$; ** $\mathrm{P}<0.01$; ***: $\mathrm{P}<0.001$. The means between the classes of the same line followed by different letters differ significantly at the threshold of $5 \%$.

The average daily gains were significantly affected by the genetic type with the best weight gains found in North ecotype. The average daily gain from birth to 120 days, from 120 days to 240 days and from the birthto 240 days were respectively of 79.48 vs $62.15 \mathrm{~g} / \mathrm{day} ; 59.72 \mathrm{vs} 51.45 \mathrm{~g} /$ day and $50.58 \mathrm{vs} 40.01 \mathrm{~g} / \mathrm{day}$ for the lambs of North and South ecotype $(\mathrm{p}<0.01)$.

Overall, the dwarf sheep of North ecotype of Benin had the best growth performances comparatively to the South ecotype.

Variation of age-type weight and average daily gain (ADG) of Djallonke sheep of Benin according to the sex:The growth performance parameters of the male and the female dwarf sheep of Djallonke breed are given in table 2 . The birth weight of the West African dwarf sheep didn't vary significantly according to the sex and was of $2.01 \pm$ $0.03 \mathrm{~kg}$ for the females and $2.07 \pm 0.03 \mathrm{~kg}$ for the males $(\mathrm{p}>0.05)$. Nevertheless, from the birth to the age of $300 \mathrm{days}$ old,the males were significantly heavier than females $(\mathrm{p}<0.001)$. 
Table 2:- Variation of age-type weight and average daily gain (ADG) according to the sex.

\begin{tabular}{|c|c|c|c|c|c|}
\hline \multirow[t]{2}{*}{ Variables } & \multicolumn{2}{|c|}{ Female $(\mathrm{N}=305)$} & \multicolumn{2}{|c|}{ Male $(\mathbf{N}=324)$} & \multirow[t]{2}{*}{ ANOVA } \\
\hline & Mean & Standard error & Mean & Standard error & \\
\hline W0 & 2.01 & 0.03 & 2.07 & 0.03 & NS \\
\hline W15 & 3.26 & 0.05 & 3.47 & 0.05 & $* *$ \\
\hline W30 & 4.31 & 0.07 & 4.56 & 0.07 & $*$ \\
\hline W45 & 5.37 & 0.10 & 5.65 & 0.09 & $*$ \\
\hline W60 & 6.34 & 0.12 & 6.79 & 0.17 & $* *$ \\
\hline W75 & 7.19 & 0.14 & 7.84 & 0.16 & $* * *$ \\
\hline W90 & 8.18 & 0.17 & 8.93 & 0.15 & $* * *$ \\
\hline W105 & 9.01 & 0.21 & 9.92 & 0.19 & $* * *$ \\
\hline W120 & 9.95 & 0.23 & 10.89 & 0.22 & $* * *$ \\
\hline W135 & 10.68 & 0.29 & 11.67 & 0.25 & $* * *$ \\
\hline W150 & 11.45 & 0.30 & 12.73 & 0.26 & $* * *$ \\
\hline W165 & 11.85 & 0.32 & 13.19 & 0.29 & $* * *$ \\
\hline W180 & 12.57 & 0.37 & 13.83 & 0.33 & $* * *$ \\
\hline W195 & 12.89 & 0.42 & 14.38 & 0.38 & $* * *$ \\
\hline W210 & 13.42 & 0.48 & 15.02 & 0.42 & $* * *$ \\
\hline W225 & 14.15 & 0.56 & 15.65 & 0.42 & $* * *$ \\
\hline W240 & 14.45 & 0.65 & 16.25 & 0.50 & $* * *$ \\
\hline W255 & 14.86 & 0.93 & 16.85 & 0.61 & $* * *$ \\
\hline W270 & 15.47 & 1.27 & 17.38 & 0.90 & $* *$ \\
\hline W285 & 16.14 & 1.32 & 17.75 & 1.17 & $*$ \\
\hline W300 & 16.67 & 1.44 & 18.26 & 1.59 & $*$ \\
\hline ADG0_120 & 64.02 & 1.85 & 72.02 & 2.77 & $* *$ \\
\hline ADG20_240 & 52.03 & 2.42 & 56.36 & 2.02 & NS \\
\hline ADG120_240 & 41.84 & 3.25 & 46.82 & 3.19 & NS \\
\hline
\end{tabular}

Wi: Live weight at I days old; ADG i_j: Average Daily gain calculated from I days to j days old; N: Number; SE: Standard Error, ANOVA: Analysis of Variance, *: $\mathrm{P}<0.05 ; * * \mathrm{P}<0.01$; ***: $\mathrm{P}<0.001$. The means between the classes of the same line followed by different letters differ significantly at the threshold of $5 \%$.

The average daily gain of the lambs female and male from birth to 120 days, from 120 days to 240 days and from birthto 240 days were respectively of 64.02 vs 72.02 g/day; 52.03 vs 56.36 g/day and 41.84 vs 46.82 g/day. The effect of sex was only significant on the average daily gain of the lambs from birth to 120 days with the higher ADG found in the males $(\mathrm{p}<0.05)$.

\section{Variation of age-type weight and average daily gain (ADG) of Djallonke sheep of Benin according to the} season:-

Table 3 shows the variabilityof growth performance of Djallonke sheep of Benin according to their season of birth. It appears that Djallonke sheep born in the rainy season were slightly heavier than those born in the dry season during the first 3.5 months (0-105 days) without any significant difference ( $>>0.05)$. At 120 and 135 days old, Djallonke dwarf sheep born in the dry season were significantly heavier than those born in the rainy season with the respective live weights of $10.71 \mathrm{Kg}$ vs $10.09 \mathrm{Kg}$ and $11.62 \mathrm{Kg} v s 10.66 \mathrm{Kg}(\mathrm{p}<0.05)$. From the age of 105 days old to 300 days, Djallonke sheep born in the rainy season remained slightly heavier than those born in the dry season but without any significant difference $(\mathrm{p}>0.05)$.

Table 3:-Variation of age-type weight and average daily gain (ADG) according to the season . 


\begin{tabular}{|c|c|c|c|c|c|}
\hline \multirow[t]{2}{*}{ Variables } & \multicolumn{2}{|c|}{ Rainyseason $(\mathrm{N}=365)$} & \multicolumn{2}{|c|}{ Dry season $(N=264)$} & \multirow[t]{2}{*}{ ANOVA } \\
\hline & Mean & Standard error & Mean & Standard error & \\
\hline W0 & 2.06 & 0.03 & 2.02 & 0.03 & NS \\
\hline W15 & 3.43 & 0.05 & 3.30 & 0.06 & NS \\
\hline W30 & 4.51 & 0.06 & 4.35 & 0.08 & NS \\
\hline W45 & 5.55 & 0.09 & 5.48 & 0.10 & NS \\
\hline W60 & 6.62 & 0.11 & 6.52 & 0.25 & NS \\
\hline W75 & 7.47 & 0.14 & 7.60 & 0.21 & NS \\
\hline W90 & 8.43 & 0.17 & 8.69 & 0.15 & NS \\
\hline W105 & 9.32 & 0.22 & 9.61 & 0.18 & NS \\
\hline W120 & 10.09 & 0.25 & 10.71 & 0.20 & $*$ \\
\hline W135 & 10.66 & 0.32 & 11.62 & 0.23 & $*$ \\
\hline W150 & 11.94 & 0.32 & 12.12 & 0.25 & NS \\
\hline W165 & 12.43 & 0.36 & 12.48 & 0.27 & NS \\
\hline W180 & 13.10 & 0.42 & 13.16 & 0.30 & NS \\
\hline W195 & 13.64 & 0.47 & 13.51 & 0.34 & NS \\
\hline W210 & 14.35 & 0.53 & 13.93 & 0.37 & NS \\
\hline W225 & 15.00 & 0.59 & 14.63 & 0.37 & NS \\
\hline W240 & 15.47 & 0.72 & 15.12 & 0.42 & NS \\
\hline W255 & 15.92 & 0.94 & 15.73 & 0.53 & NS \\
\hline W270 & 16.77 & 1.63 & 15.90 & 0.66 & NS \\
\hline W285 & 17.20 & 1.75 & 16.34 & 1.89 & $\mathrm{NS}$ \\
\hline W300 & 17.70 & 1.95 & 16.81 & 1.87 & NS \\
\hline ADG0_120 & 64.73 & 2.81 & 71.07 & 1.28 & $*$ \\
\hline ADG20_240 & 59.04 & 2.88 & 51.90 & 1.66 & $*$ \\
\hline ADG120_240 & 48.83 & 3.37 & 40.34 & 3.01 & NS \\
\hline
\end{tabular}

Wi: Live weight at I days old; ADG i_j: Average Daily gain calculated from I days to $\mathrm{j}$ days old; N: Number; SE: Standard Error, ANOVA: Analysis of Variance, ${ }^{*}: \mathrm{P}<0.05$. The means between the classes of the same line followed by different letters differ significantly at the threshold of $5 \%$.

The average daily gains of dwarf sheep of Djallonke Breed of Benin were also affected by the born season of the lambs. Indeed, the average daily gains of dwarf sheep of Djallonke Breed from the birth to the age of 120 days was significantly better $(\mathrm{p}<0.05)$ in lambs born in the rainy season than the values recorded in dry season $(71.07 \mathrm{~g} / \mathrm{day} \pm$ $1.28 \mathrm{vs} 64.73 \mathrm{~g} / \mathrm{day} \pm 2.81)$. On the over hand, ADG calculated from the birth to 240 days old was significantly higher $(\mathrm{p}<0.05)$ in animals born in the rainy season $(59.04 \pm 2.88 \mathrm{~g} /$ day $)$ than those born in the dry season $(51.90 \pm$ $1.66 \mathrm{~g} /$ day). However, no significant difference was found between theaverage daily gains of dwarf sheep of Djallonke Breed of Benin born in dry or rainy season from 120 days to 240 days old, even if the lambs born in dry season seems to gain more in weight than lambs born in rainy season.

Variation of age-type weight and average daily gain (ADG) of Djallonke sheep of Benin according to the lambing rank:-

The variability of age-type weight and average daily gain (ADG) of Djallonke sheep of Benin according to the lambing rank is given in table 4. Except the live weights recorded at 225, 240 and 255 days old which varied significantly according to the lambing rank, the other age-type weights measured herein were not affected by lambing rank. The highest live weights found at 225, 240 and 255 days (respectively $19.42 \mathrm{~kg}, 20.47 \mathrm{~kg}$ and 19.53 $\mathrm{kg}$ ) were recorded at the second lambing rank $(\mathrm{p}<0.05)$. Overall, the lambs born at the second, third and to a lesser extend the fourth lambing rank tend to be heavier than those born at the first and fifth lambing rank. Average daily gains were not affected by the lambing rank ( $p>0.05$ ). However, Djallonke sheep born from the lambing ranks 1 and 5 showed the lowest average daily gain $(p>0.05)$. 
Table 4:-Variation of age-type weight and average daily gain (ADG) according to the lambing rank.

\begin{tabular}{|c|c|c|c|c|c|c|c|c|c|c|c|}
\hline \multirow[t]{3}{*}{ Variable } & \multicolumn{8}{|c|}{ Lambingrank (LR) } & & & \multirow[t]{3}{*}{ ANOVA } \\
\hline & \multicolumn{2}{|c|}{ LR1 } & \multicolumn{2}{|c|}{ LR2 } & \multicolumn{2}{|c|}{ LR3 } & \multicolumn{2}{|c|}{ LR4 } & \multicolumn{2}{|c|}{ LR5 } & \\
\hline & Mean & $\mathbf{S E}$ & Mean & SE & Mean & SE & Mean & $\mathbf{S E}$ & Mean & SE & \\
\hline W0 & 1.95 & 0.08 & 2.19 & 0.15 & 2.08 & 0.09 & 2.14 & 0.07 & 1.92 & 0.18 & NS \\
\hline W15 & 3.36 & 0.12 & 3.61 & 0.18 & 3.70 & 0.15 & 3.74 & 0.14 & 3.13 & 0.16 & NS \\
\hline W30 & 4.72 & 0.20 & 4.86 & 0.25 & 5.00 & 0.24 & 5.03 & 0.19 & 4.32 & 0.15 & NS \\
\hline W45 & 5.92 & 0.28 & 6.23 & 0.30 & 6.44 & 0.28 & 5.76 & 0.22 & 5.61 & 0.21 & NS \\
\hline W60 & 6.71 & 0.41 & 7.42 & 0.43 & 7.34 & 0.28 & 6.76 & 0.32 & 6.55 & 0.31 & NS \\
\hline W75 & 7.48 & 0.60 & 8.36 & 0.56 & 8.64 & 0.33 & 7.81 & 0.38 & 7.79 & 0.23 & NS \\
\hline W90 & 8.55 & 0.62 & 9.44 & 0.69 & 9.19 & 0.38 & 8.86 & 0.4 & 8.05 & 0.38 & NS \\
\hline W105 & 9.29 & 0.65 & 11.22 & 0.81 & 10.16 & 0.42 & 9.72 & 0.46 & 8.37 & 0.20 & NS \\
\hline W120 & 10.52 & 0.54 & 12.43 & 0.76 & 11.43 & $0 . .42$ & 10.11 & 0.52 & 8.88 & 0.69 & NS \\
\hline W135 & 11.42 & 0.58 & 13.02 & 0.96 & 12.35 & 0.46 & 11.53 & 0.67 & 9.65 & 0.98 & NS \\
\hline W150 & 12.59 & 0.62 & 13.63 & 0.97 & 13.43 & 0.47 & 11.84 & 0.66 & 10.59 & 1.20 & NS \\
\hline W165 & 13.52 & 0.73 & 14.22 & 0.95 & 14.20 & 0.59 & 12.47 & 0.76 & 11.62 & 0.97 & NS \\
\hline W180 & 14.03 & 0.70 & 15.21 & 0.85 & 14.89 & 0.60 & 13.25 & 0.83 & 12.47 & 1.05 & NS \\
\hline W195 & 14.82 & 0.82 & 16.01 & 0.94 & 15.51 & 0.70 & 13.91 & 0.92 & 12.87 & 1.11 & NS \\
\hline W210 & 15.28 & 0.86 & 18.81 & 0.91 & 16.27 & 0.73 & 15.17 & 0.69 & 13.65 & 0.81 & NS \\
\hline W225 & $15.72 \mathrm{a}$ & 0.69 & $19.42 b$ & 0.99 & $17.04 a b$ & 0.92 & $15.63 \mathrm{ab}$ & 0.66 & $14.26 \mathrm{ab}$ & 1.05 & * \\
\hline W240 & $15.87 \mathrm{a}$ & 1.19 & $19.53 b$ & 1.02 & 17.51ab & 0.98 & $16.43 \mathrm{ab}$ & 0.81 & $15.17 \mathrm{ab}$ & 1.13 & * \\
\hline W255 & $16.01 \mathrm{a}$ & 1.75 & $20.47 b$ & 1.23 & $18.05 \mathrm{ab}$ & 1.14 & $17.83 \mathrm{ab}$ & 1.04 & $16.10 \mathrm{ab}$ & 1.29 & * \\
\hline W270 & 16.94 & 2.25 & 20.59 & 1.12 & 19.42 & 1.32 & 18.06 & 1.60 & 16.72 & 1.67 & NS \\
\hline W285 & 17.38 & 2.42 & 20.63 & 1.32 & 19.44 & 1.49 & 19.11 & 1.60 & 17.22 & 1.63 & NS \\
\hline W300 & 17.96 & 2.15 & 20.71 & 1.44 & 19.57 & 1.65 & 19.23 & 1.65 & 17.91 & 2.04 & NS \\
\hline ADG0_120 & 73.36 & 4.88 & 81.92 & 6.08 & 81.48 & 3.84 & 66.94 & 5.11 & 71.17 & 6.12 & NS \\
\hline ADG20_240 & 56.58 & 2.48 & 68.11 & 6.14 & 66.66 & 7.46 & 60.31 & 4.21 & 57.60 & 7.65 & NS \\
\hline ADG120_240 & 49.66 & 6.37 & 55.95 & 8.78 & 59.09 & 4.42 & 47.18 & 4.82 & 38.08 & 3.51 & NS \\
\hline
\end{tabular}

Wi: Live weight at I days old; ADG i_j: Average Daily gain calculated from I days to j days old; N: Number; SE: Standard Error, ANOVA: Analysis of Variance, *: $\mathrm{P}<0.05$. The means between the classes of the same line followed by different letters differ significantly at the threshold of $5 \%$.

Variation of age-type weight and average daily gain (ADG) of Djallonke sheep of Benin according to the type of birth (litter size):-

Table 5 shows the variation of growth performance of sheep Djallonke according to type of birth. The effect of the type of birth weight on the West African dwarf sheep was highly significant $(\mathrm{p}<0.001)$ on birth weight, the age-type weights recorded $15,30,45,60,75,90,105$, and 120 days and the average daily gain calculated from the birth to the age of 120 days.

Table 5:-Variation of age-type weight and average daily gain (ADG) according to the type of birth.

\begin{tabular}{|c|c|c|c|c|c|c|c|c|c|}
\hline \multirow[t]{3}{*}{ Variables } & \multicolumn{8}{|c|}{ Type of birth (liter size) } & \multirow[t]{3}{*}{ ANOVA } \\
\hline & \multicolumn{2}{|c|}{ Single } & \multicolumn{2}{|c|}{ Double } & \multicolumn{2}{|c|}{ Triple } & \multicolumn{2}{|c|}{ Quadruplet } & \\
\hline & Mean & SE & Mean & SE & Mean & SE & Mean & SE & \\
\hline W0 & $2.09 \mathrm{a}$ & 0.23 & $2.01 \mathrm{a}$ & 0.20 & $1.89 \mathrm{~b}$ & 0.18 & $1.13 \mathrm{ab}$ & 0.24 & * \\
\hline W15 & $3.59 \mathrm{a}$ & 0.39 & $3.19 \mathrm{~b}$ & 0.29 & $3.01 \mathrm{~b}$ & 0.48 & $3.09 \mathrm{ab}$ & 0.74 & $* * *$ \\
\hline W30 & $4.89 \mathrm{a}$ & 0.49 & $4.04 \mathrm{~b}$ & 0.45 & $3.97 \mathrm{~b}$ & 0.23 & $3.99 \mathrm{ab}$ & 0.67 & $* * *$ \\
\hline W45 & $6.05 \mathrm{a}$ & 0.79 & $5.02 \mathrm{~b}$ & 0.46 & $5.08 \mathrm{~b}$ & 0.69 & $4.69 \mathrm{ab}$ & 1.12 & $* * *$ \\
\hline W60 & $7.15 \mathrm{a}$ & 0.53 & $6.02 \mathrm{~b}$ & 0.78 & $5.94 \mathrm{~b}$ & 0.88 & $6.96 \mathrm{ab}$ & 0.65 & $* * *$ \\
\hline W75 & $8.07 \mathrm{a}$ & 0.87 & $6.99 \mathrm{~b}$ & 0.74 & $7.28 \mathrm{ab}$ & 0.87 & $7.83 \mathrm{ab}$ & 0.97 & $* * *$ \\
\hline W90 & $9.15 \mathrm{a}$ & 0.99 & $7.93 \mathrm{~b}$ & 0.63 & $8.37 \mathrm{ab}$ & 0.56 & $9.11 \mathrm{ab}$ & 0.95 & **** \\
\hline W105 & $10.00 \mathrm{a}$ & 0.71 & $8.91 \mathrm{~b}$ & 0.30 & $9.27 \mathrm{ab}$ & 0.41 & $9.74 a b$ & 0.91 & $* * *$ \\
\hline W120 & $10.77 \mathrm{a}$ & 0.74 & $10.08 \mathrm{~b}$ & 0.78 & $9.78 \mathrm{ab}$ & 0.74 & $10.53 \mathrm{ab}$ & 0.80 & * \\
\hline W135 & 11.45 & 0.93 & 10.97 & 0.99 & 9.78 & 0.52 & 11.54 & 0.58 & NS \\
\hline W150 & $12.31 \mathrm{a}$ & 0.97 & $11.87 \mathrm{ab}$ & 0.86 & $10.14 \mathrm{~b}$ & 0.64 & $12.34 \mathrm{ab}$ & 0.45 & * \\
\hline W165 & 12.66 & 1.11 & 12.42 & 0.87 & 10.58 & 0.98 & 11.98 & 0.58 & NS \\
\hline
\end{tabular}




\begin{tabular}{|l|c|c|c|c|c|c|c|c|c|}
\hline W180 & 13.32 & 0.22 & 13.07 & 0.46 & 11.33 & 1.22 & 12.57 & 0.94 & NS \\
\hline W195 & $13.71 \mathrm{a}$ & 0.35 & $13.60 \mathrm{ab}$ & 0.42 & $11.78 \mathrm{~b}$ & 1.10 & $12.73 \mathrm{ab}$ & 0.27 & $*$ \\
\hline W210 & $14.54 \mathrm{a}$ & 0.48 & $13.90 \mathrm{a}$ & 0.49 & $12.77 \mathrm{~b}$ & 0.14 & $14.00 \mathrm{ab}$ & 0.23 & $* *$ \\
\hline W225 & $15.21 \mathrm{a}$ & 0.63 & $14.48 \mathrm{ab}$ & 0.53 & $13.38 \mathrm{ab}$ & 0.93 & $14.85 \mathrm{~b}$ & 0.89 & $*$ \\
\hline W240 & 15.89 & 1.16 & 14.74 & 0.73 & 13.81 & 0.64 & 14.86 & 0.54 & $\mathrm{NS}$ \\
\hline W255 & 16.28 & 1.54 & 15.38 & 0.77 & 14.02 & 0.85 & 14.46 & 0.81 & $\mathrm{NS}$ \\
\hline W270 & 17.00 & 1.67 & 15.86 & 0.67 & 15.61 & 0.34 & 15.78 & 1.10 & $\mathrm{NS}$ \\
\hline W285 & 17.43 & 1.66 & 16.26 & 0.91 & 16.69 & 0.49 & 17.12 & 2.58 & NS \\
\hline W300 & 18.04 & 1.95 & 16.65 & 1.09 & 17.20 & 0.72 & 18.16 & 1.64 & $\mathrm{NS}$ \\
\hline ADG0_120 & $72.37 \mathrm{~b}$ & 1.87 & $64.35 \mathrm{a}$ & 1.74 & $65.15 \mathrm{ab}$ & 4.84 & $60.16 \mathrm{ab}$ & 3.84 & $*$ \\
\hline ADG20_240 & 56.42 & 2.23 & 53.75 & 2.33 & 48.86 & 1.80 & 47.96 & 4.10 & $\mathrm{NS}$ \\
\hline ADG120_240 & 47.04 & 3.89 & 41.93 & 2.69 & 44.63 & 4.50 & 46.45 & 3.47 & $\mathrm{NS}$ \\
\hline
\end{tabular}

Wi: Live weight at I days old; ADG i_j: Average Daily gain calculated from I days to $\mathrm{j}$ days old; N: Number; SE: Standard Error, ANOVA: Analysis of Variance, *: $\mathrm{P}<0.05$; ** $\mathrm{P}<0.01$; ***: $\mathrm{P}<0.001$. The means between the classes of the same line followed by different letters differ significantly at the threshold of $5 \%$.

Overall, the birth weight of sheep Djallonke born alone (single birth) was higher than those of sheep born indouble, triple and quadruplelitters. The lambing from triple litter size showed the lowest live weightsfrom from the 120th day of age.The type of birth had affected the average daily gain from 0 to 120 days $(\mathrm{p}<0.05)$ with the highest weight gain recorded in the single litter size and the lowest in the litter size of five lambs. However, the type of birth or the litter size didn't influence theaverage daily gain from 0 to 240 days and the one from 120 days to 240 days (p $>0.05$ ).

\section{Discussion:-}

\section{Effect of ecotype:-}

Our results showed that birth weight were similar for the two ecotypes and are $2.01 \mathrm{~kg}$ and $2.07 \mathrm{~kg}$ respectively for lambs of North and South ecotypes. In north Benin (Banikoara), Youssao et al. (2008) obtained a birth weight of $1.88 \pm 0.32 \mathrm{~kg}$ in lambs of the same breed. DokoAllou et al. (2013) found $1.82 \pm 0.49 \mathrm{~kg}$ in the same agroecological area whileGbangboche et al. (2005b) had reported a birth weight varying from 1.77 to $1.89 \mathrm{~kg}$ at the National Breeding Farm of Okpara, District of Tchaourou in Benin. These different reported birth weights are lower than those obtained in our study for Djallonké Dwarf sheep of North ecotype. However, our results are comparable to the values varying from $1.9 \mathrm{~kg}$ to $2.04 \mathrm{~kg}$ reported by Gbangboche et al. (2005a) for sheep Djallonkereared on natural pasture at the National Breeding Farm of Bétécoucouin Benin. The birth weight found by NaandamAmoahOtchere (2014) in traditional breeding in Ghana isof $1.6 \mathrm{~kg}$; this performance is lower than those obtained in our results.

In traditional breeding in North Benin, Youssao et al. (2008) obtained a live weight of $10.56 \pm 1.88 \mathrm{~kg}$ at 3 months of age. This weight is greater than the value of $9.41 \pm 2.07 \mathrm{~kg}$ obtained herein at the same age. The live weight at 3 months of age found by NaandamAmoah-Otchere (2014) in traditional breeding in Ghana was higher than those obtained in our study and was of $10.7 \mathrm{~kg}$. However, the weight obtained in this study after the third month is higher than the weight of $8.22 \pm 3.41 \mathrm{~kg}$ reported by DokoAllou et al. (2013) in Djougou in Benin.

The performances differences observed herein compared with other breeds could be attributed to the rearing conditions (management, herdsman skills, levels of diseases, and trypanosome risk....) and the genetic type of the West African dwarf sheep used by the authors.

Several authors concluded, in fact, that the genotype or the breeds of sheep reared under comparable conditions havefrequently different age-type weight and average daily gains (Boly et al., 2000; Gbangboche 2005a; Doko Alou et al., 2013). These authors linkedit to several factors including the genetic type and natural selection (Lebbie and Ramsay, 1999; Gbangboche, 2005b; Youssao, 2008). This reality is highlighted by the results of our study which show that Djallonke Dwarf sheep of North ecotype were significantly heavier with fast growth rate than South ecotype.

Poivey et al. (1982) reported high heritability for weight at three months of age and suggest taking this into account in the selection of dwarf sheep. It is therefore proven that the crossbreedsSahelianx West African dwarf sheep 
express best growth performancesthan pure Djallonke breed (Amégé, 1984) and could be perceived as an alternative of improvement of the profitability of sheep rearing (Gbangboché et al., 2002). Thus, the crossingbetween Djallonke sheep of North ecotype x South ecotypecan improve the growth performances of South ecotype of Djallonke sheep and preserve their resistance to illness and the identity of the Djallonke breed.

It is important to show that the weight difference found herein between Djallonke Dwarf sheep of North and South ecotypes of Benin seems to disappear from the 10th month with an apparent reversal of the original trend. We can therefore understand that the West African dwarf sheep reach their adult weight at this age of 10 months and their weight growth becomes less rapid.

The weights obtained at the 10th month of age in the dwarf sheeps of North and South ecotype are respectively $17.73 \pm 1.84 \mathrm{~kg}$ and $16.96 \pm 1.50 \mathrm{~kg}$. These weights are lower than the value of 30kgobtained by Amégé (2004) for Vogan sheep at 7 months old and the live weight of $37.3 \mathrm{~kg}$ reported for Lohi sheep of 9 months old by Iashari and Tasawar (2013). These confirm that the growth performances of the West African dwarf sheep reared in Beninhave relatively very low growth performance and need improvement program.

\section{Effect of sex:-}

Our results show that the birth weight of the West African dwarf sheep showed no significant difference among males and females. This finding is contrary to those reported by some authors stating that in the same rearing conditions, males born heavier than females (Fall et al., 1983; Poiveyet al., 1982 Abaffa et al., 1992). However,sex effect was significant for all traits in Djallonke lambs from 15days old to the end of the experiment. Males were significantly heavier than females.

Such differences have been documented by a number of investigators (Adu et al., 1985; Mavorogenis and Constanntinous, 1986; Movarogenis and Constantinou, 1986; Nawaz and Khalil 1998; Rastogi 2001; Gbangboche et al., 2005a).

According to these authors, the sex affects many productivity of Djallonkesheep in favor of males; they are usually born heavier than females and keep this trend up to the age of 12 months or more. The same observations were made by several authors on other ruminants such as goats (Haumesser, 1975; Umara, 1986; Alexander et al., 1997; Hounkpevi, 2005; and Adjibode, 2012), and cattle (Youssao et al., 2000). However, according Abaffa et al. (1992), the effect of sex would tend to disappear from 120 days in sheep. The larger weight of males in comparison to female lambs could be due to the hormonal differences in their endocrinological and physiological functions (Ebangi et al., 1996).

The average daily gain from the birth to the age of 4 months showed significant differences according to the sex. The same observations were made in dwarf goats by Adjibode (2012) and this phenomenon can be justified by the fact that the heaviest born males are more competitive than females in the consumption of milk (Ba Diao et al., 1994).

\section{Effect of the season:-}

Our findings show only an apparent difference (not significant) between the age-type weights of Djallonkesheep accordingto the season except the weight at 120 days which was significantly higher in animals born in the dry season. This exceptional difference is explained by the fact that these animals born in the dry season deal at this age a favorable nutritional period (rainy season) soon after their weaning, unlike those born in the rainy season which undergo (at this age) difficulties of the dry season. However outside the average daily gain calculated for the period from 120 days to 240 days showed no significant difference, the other daily average gains varied significantly depending on the season of birth in favor of animals born in the dry season. According to Berhanu and Aynalem (2009), the effect of season is associated with difference in feed and disease situation. When lambing occurred during wet season there is high incidence of parasite infestation impairing growth performance.

Moreover, if for Abaffa (1992), animals born between November and December (dry season) show the best performance, Gbangboche et al. (2005a) found that the rainy season is the most favorable and beneficial to the West African dwarf sheep not only by promoting a lambing peak but also by increasing the weight of lambs at birth and at 12 months and by promoting a reduction of age at first calving and lambing interval. The notion of season is a vast field that must be considered with attention in animal experimentation as including several parameters. 
According to the findings of Attindehou et al. (2012), animals that lack of rigorous medical follow-up show slow growth rate due to the parasitic diseases that develop during the rainy period while Tiema (2011) reported poor diet as one of the factors that impact the morbidity and therefore the growthperformance of lambs in village farms. In addition, several authors concluded that the season of birth postpone the puberty according to the energy restriction, high ambient temperatures and high relative humidity (Skinner and Rowson, 1968; Good et al., 2005; Delgadillo et al., 2007; Marai et al., 2007; Marai et al., 2008).

\section{Effect of lambing rank:-}

In the current study, the animals born from the second, third and fourth parturition showed the best growth performance than animals born from the first and the fifth lambing rank. Our findings are in accordance with the reports of several authors (Fall et al., 1982; Poivey et al., 1982; Filius et al., 1986; Abaffa et al., 1992; London et al., 1994; Yapi-Gnaoré et al., 1997).This remark can be due to the age and the live weight of primiparous ewes because the females do not usually reach their physiological maturity at the first lambing and their own growth competes with that of their product (Poivey et al., 1982; and Yapi-Gnaoré al., 1997).

Contrary to our finding, Ba Diao et al. (1994) indicated in goats that the lambing rank has a significant effect on weight gain in kids with the observation that the higher the rank of farrowing evolves, less animals are heavy. This difference in outcome could be explained by the fact that on one hand the litter size in goats are evolving with the rank of farrowing. Moreover, the milking of multiparous goats isgenerally observed and could reduce the availability of milk for kids of advanced lambing rank.

No significant difference was observed in the present study among the average daily gains according to the lambing rank. This result differsfrom those of Youssao et al. (2008) who found that the average daily gain from birth to the age of 90 days is significantly influenced by the lambing rank.

\section{Influence of type of birth:-}

Our results generally show that the weight of sheep Djallonkeborn alone (single birth) were higher than those of sheep from twin, triple and quadruple litters. These results corroborate those of Poivey et al. (1982) which stipulate that single lambs were heavier than those from multiple birth and no systematic compensatory growth is observed after weaning. Furthermore, this could be caused by the poor milk production of the local ewe (Gbangboche et al., 2005a). A similar effect of birth type has been well documented for dwarf sheep (Yapi-Gnaoré et al., 1997; Gbangboche et al., 2005a) and Wall sheep (Ebangi et al., 2001).

Furthermore, it should be noted that although the single born animals have the advantage to reachthe puberty at a younger age (Boussena, 2013), but have the disadvantage of having a smaller weight productivity at birth and at 12 months old than double born animals (Gbangboche et al., 2005a).

\section{Conclusion:-}

The study clarifies the factors of variation of the growth performance of Dwarf sheep of Djallonke breed reared under traditional rearing system in Benin. The North ecotype of West African dwarf sheep grows faster and weigh more than those of South ecotype. Moreover, the lambs born from primiparous ewes were lighter than lambs born from multiparous ewes.

The variability observed in growth performance between Djallonkelambs of North and South ecotypes of Benin suggested that genetic diversity exists which could be exploited for genetic improvement. This can be organized through ram progeny testing in order to identify sires for producing fast growing lambs. These programs should involve the faster growing lambs selected from ewes with high rearing ability in farmers flock within the same agro ecological areas.

The results of this study can also be a basis to improve local ecotypes of Djallonkesheeps of Benin through conservation-based with-in breed selection with a participation of traditional sheep breeders. The difference in weight between sexes is pronounced as age advances. Male lambs had higher weights than females.Furthermore,non-genetic factors involved in this study need to be taken into account to improve sheep production and accurate estimation of genetic parameters. 
To better characterize Djallonke Dwarf Sheep of North and South eotypes of Benin, further studies with large data set on their rearing systems, reproductive performance, morpho-biometrical parameters carcass and genital organs and semen quality traits would be very useful.

\section{Acknowledgements:-}

The authors are grateful to the ministry of the higher education and scientific research of Benin.

\section{References:-}

1. Abassa, K.P., Pessinaba, J. andAdeshola-Ishola, A. (1992): Croissance pré-sevrage des agneaux Djallonké au Centre de Kolokopé (Togo).Revue Elev. Méd. vét. Pays Trop., 45 (1), 49-54.

2. Aboh, A.B., Ehouinsou, M.A., Olaafa,M. and Brun, A.(2008): Complémentation alimentaire des ovins Djallonké avec les sous-produits de transformation d'ananas : potentiel nutritif, préférence et développement pondéral. Bulletin de la RechercheAgronomique du BéninNuméro 61 - Septembre 2008, 25-30.

3. Adjibode, A.G.(2012) : Facteurs non génétiques influençant les paramètres zootechniques de la chèvre naine en zone soudanienne du Bénin. Mémoire présenté en vue de l'obtention du diplôme de master en production et santé animales, EPAC/UAC, 91p.

4. Akouèdégni, C.G., GbégoTossa, I., Ahoussi, E., Hounzangbé-Adoté, M.S.(2013) :Effects of the fresh leaves of Spondiasmombin L. on milk production of West African Dwarf (WAD) ewes and their lamb's growth performance, Global J Res. Med. Plants \&Indigen. Med., 2(3): 126-134

5. Alexandre, G., Aumont, G., Fleury, J., Mainaud, J.C. andKandassamy, T.(1997) : Performances zootechniques de la chèvre créole allaitante de Guadeloupe. Bilan de 20 ans dans un élevage expérimental de l'Inra. Prod. Anim., $10: 7-20$.

6. Amégé, Y.(1984) : Le mouton de Vogan (croisé Djallonké x Sahélien) au Togo : II. Valeur bouchère des agneaux non engraissés. Rev. Elev. Méd. Vét. Pays Trop., 37, 91-96.

7. Attindehou, S., Salifou, S., Daga, D.F., Gbangboché, A.B., Gbati, O.B. andPangui L.J.(2012) : Stomach fluke infection in sahelian and West African dwarf small ruminants in Benin, International Multidisciplinary Research Journal 2012, 2(8):01-03.

8. Awohouedji, D.Y.G., Babatounde, S., Adounkpe, J.G., Houinato, M., Hounzangbe-Adote, S.(2013): Supplementing panicum maximum with two medicinal forages in the diet of Djallonke sheep at the Benin national sheep center,Scientific Journal of Animal Science 2(11) 284-295.

9. Ayuk, A., Iyayi, E., Okon, B. and Ayuk, J. (2014): Growth Performance of West African Dwarf (WAD) Sheep Fed Biodegraded Enterolobiumcyclocarpum Based Diets. Agricultural Sciences, 5, 710-715. doi: 10.4236/as.2014.58074.

10. Ba Diao, M., Gueye, A. andSeck, M.(1994) : Facteurs de variation de la production laitière des caprins en milieu peul, Institut sénégalais de recherches agricoles, Direction des recherches sur les productions et la santé animales, Dakar-Hann (Sénégal), FAO, 18p.

11. Babatounde, S., Oumorou, M., Tchabi, I.V., Lecomte, T., Houinato, M. andAdandedjan, C. (2010):Ingestion volontaire et préférences alimentaires chez des moutons Djallonkénourris avec des graminées et des légumineuses fourragères tropicalescultivées au Bénin, Int. J. Biol. Chem. Sci. 4(4): 1030-1043.

12. Babatoundé, S., Saïdou, A., Guidan, M. and Mensah, G.A.(2009) : Effet d'une complémentation alimentaire à base de légumineuses fourragères cultivées (ChamaecristarotundifoliaetAeschynomenehistrix) sur les performances des ovins Djallonké. Renc. Rech. Ruminants, 16, 54.

13. Berhanu, B. and Aynalem H. (2009): Factors affecting growth performance of sheep under village management conditions in the south western part of Ethiopia. Livestock Research for Rural Development 21 (11).

14. Boly, H., Peneme, B.M.L., Sawadogo, L., Sulon, J., Beckers, J.F. and Leroy, P.L.(2000):Effet dose réponse de la gonadotropine (PMSG) sur la reproduction de la brebis Djalonké variété 'Mossi'. Tropicultura, 18, 126129.

15. Bonnes, G., Desclaude.J., Drogoul, C., Gadoud, R., Jussisau, R., Le Loc'h, A., Montmeas, L. and Robin, G.(2005) : Reproduction des animaux d'élevages. 2 ème Edition ; Dijon Educagri (Ed.): 407 p.

16. Boussena, S., Bouaziz, O., Zerrougui, S., Derqaoui, L. andTainturier, D.(2013) Performances de croissance corporelle et testiculaire avant le sevrage chez les agneaux de race OuledDjellal, Revue Méd. Vét., 164, 4, 191199.

17. CountryStat (2016): Répartition des effectifs d'animaux http://www.countrystat.org/home.aspx?c=BEN\&ta=053SPD135\&tr=21 consulté le 06/05/2016. 
18. CSAO-OCDE/CEDEAO(2008): Élevage et marché régional au Sahel et en Afrique de l'Ouest Potentialités et défis, Edition : Club du Sahel et de l'Afrique de l'Ouest/OCDE, 182p.

19. CTA(2006) : Elevages des caprins, programme de radio rurale $\mathrm{N}^{\circ}$ 06/2, RRRP 2006/02, 39p

20. Delgadillo, J.A., Malpaux, B. and Chemineau, P.(1997). La reproduction des caprins dans les zones tropicales et subtropicales, INRA Prod. Anim., 10 (1), 33-41.

21. DokoAllou, S., Farougou, S., Hountondji, F.C.C. (2013): Impact of prophylactic measures and the use of local food resources on the viability and growth of pre-weaning lambs in Djougou, in the northern region of Benin, Journal of Animal \&Plant Sciences, Vol.19, Issue 3: 2933-2940

22. Ebangi, A.L., Njoya A, Ngo-Tama, A.C., Awa, D.N. and Mbah, D.A. (2001). Genetic and phenotypic parameters of birth weight traits in Fulbe sheep in Cameroon. Revue. Elev. Méd. Vét. Pays trop. 24 (2) $147-$ 151.

23. Fall, A., Gueye, E. H., Diop, M., Sandford, J., Wissocq, J.Y., Durquin, J., Trail, J.C.M.(1982): Evaluation des productivités des ovins taurins et des taurins Ndama au Centre de Recherches zootechniques de Kolda, Sénégal. Institut sénégalais de Recherches agricoles (ISRA)-Centre International pour l'Elevage en Afrique, Addis-Abeba (Cipea), pp74.

24. Fall, A., Diop, M., Sandford, J., Gueye, E., Wissocq, Y.J., Durkin, J., Trail, J.C.M.(1983): Etude sur la productivité de moutons Djallonké au Centre de Recherches Zootechniques de Kolda, au Sénégal : 2. Poids corporels, productivité des brebis et du troupeau. Revue Elev. Méd. vét. Pays Trop., 36 (3), 283-289.

25. Filius, P., Weniger, J.H andTeuscher, T.(1986): Investigations on the performance of Djallonké sheep. Animal Research and Development 24: 85-97.

26. Gbangboché, A.B., Abiola, F.A., Laporte, J.P., Salifou, S., Leroy, P.L. (2002):Amélioration des ovins dans l'Ouémé et le Plateau en République du Bénin. Enjeux de croisement des ovins Djallonké avec les moutons du Sahel, TROPICULTURA, 20, 2, 70-75

27. Gbangboché, A.B., Hounzangbé-Adoté, S.M., Doko, S.Y., Farnir, F., Detilleux, J., Leroy, P.L.(2004): Production des ovins Djallonké en station dans la zone guinéenne au Bénin : 1. Performances de reproduction et influence des facteurs non génétiques. RASPA 2 (1), 49-55.

28. Gbangboche, A.B., Abiola, F.A., Michaux, C. and Leroy, P.L.(2005a). Paramètres génétiques et non-génétiques des caractères de croissance du mouton Djallonké au Bénin, Renc. Rech. Ruminants, 12

29. Gbangboche, A.B., Hornich, J.-L., Adamou-N'diaye, M., Edorh, A.P.,Fanir, F.,Abiola, F.A. and Leroy, P.L.(2005b). Caractérisation et maîtrise des paramètres de la reproduction et de la croissance des ovins Djallonké (Ovisamonaries). Ann. Méd. Vét, 149, 170-182.

30. Haumesser, J.B.(1975) : Quelques aspects de la reproduction chez la chèvre rousse de Maradi. Comparaison avec d'autres races tropicales ou subtropicales. Revue Elev. Méd. vét. Pays trop.,28: 225-234.

31. Hounkpevi, D.A.(2005) : Elevage et amélioration génétique de la croissance des bovins Borgou de la ferme Okpara en République du Benin, mémoire présenté en vue de l'obtention du diplôme d'études spécialisées en gestion des ressources animales et végétales en milieux tropicaux, Production animale, $89 \mathrm{p}$.

32. Hounzangbe-Adote, M.S., Linton E., Koutinhouin, G.B., Losson, B. andMoutairou, K.(2001):Impact des tiques sur la croissance des agneaux Djallonké. Ann. Méd. Vet. 145, 210-216

33. Lashari, M.H. andTasawar, Z. (2013): Genetic potentials of Lohi sheep of Multan, Pakistan, Scientific Journal of Animal Science, 2(9) 254-263, ISSN 2322-1704

34. Lalit et al., 2016

35. Lebbie, S.H.B., Ramsay, K. (1999) : A perspective on conservation and management of small ruminant genetic resources in the sub-Saharan Africa. Small Rumin. Res., 34, 231-247.

36. London, J.C., Weniger, J.H. and Schwartz, H.J.(1994): Investigation into traditionnaly managed Djallonkésheep productionin humid and subhumid zones of Asante, Ghana. II. Reproductive events and prolificacy. $J$. Anim. Breed. Genet. 111, 432-450.

37. London, J.C. andWeniger, J.H.(1996): Investigation into traditionnaly managed Djallonké-sheep production in humid and subhumid zones of Asante, Ghana. V. Productivity indices. J. Anim. Breed. Genet., 113, 483-492.

38. Mawuena, K. (1987) : Haut degré de tolérance à la trypanosomose des moutons et des chèvres de race Naine Djallonké des régions sud-guinéennes du Togo : comparaison avec les bovins trypanotolérants. Rev. Elev. Méd. Vét.Pays Trop., 40, 55-58.

39. Naandam, J. andAmoah-Otchere, K.(2014). Pre-Weaning Performance of Lambs under Traditional System of Production in Northern Ghana, International Journal of Innovation and Applied Studies, ISSN 2028-9324 Vol. 5 No. 1, pp. 43-48.

40. Oumara, A. D. (1986) : Croissance et viabilité de la chèvre rousse de Maradi au Centre d'élevage caprin de Maradi (Niger), Thèse Doct. vét.,Eismv, Dakar, Sénégal, 122 p. ( $\left.{ }^{\circ} 22\right)$ 
41. Poivey, J.P., Landais, E. and Berger, Y. (1982) : Etude et amélioration génétique de la croissance des Djallonké. Résultats obtenus au Centre de Recherches Zootechniques de Bouaké (Côte-d'Ivoire). Revue Elev. Méd. Vét. Pays Trop, 35 (4), 421-433.

42. Tiéma, N.(2011) : Performances de reproduction et accroissement numérique du cheptel ovin dans deux noyaux d'élevage traditionnel en zone soudano-sahélienne au Mali.http://www.fao.org/wairdocs/ilrix5473b/x5473b29.htm

43. Vallerand, F. andBranckaert, R. (1975):La race ovine Djallonké au Cameroun. Potentialités zootechniques, conditions d'élevage, avenir. Revue. Elev. Méd. Vét. Pays trop, 28, 523-545.

44. Yapi, C.V.(1994): Caractères phénotypiques de différenciation et de croissance des agneaux de race pure Djallonké et croisés Sahélien x Djallonké. In: Proc. 2nd Biennial conference of the African Small Ruminant Res. Network, Arusha, Tanzania, December 7-11, 1992, p. 215-219.

45. Yapi-Gnaoré, C.V., Oya, A., Rege, J.E.O. andDagnogo, B.(1997): Analysis of an open nucleus breeding programme for Djallonke sheep in the Ivoiry Coast. 1. Examination of non-geneticsfactors. Animal Science, 64: 291-300.

46. Youssao, A.K.I., Ahissou, A., Michaux, C., Famir, F., Toure, Z., Idrissou, N.-D. and Leroy P.L.(2000) : Facteurs non génétiques influençant le poids et la croissance de veaux de race Borgou à la ferme d'élevage de l'Okpara au Bénin. Revue Elev.Med. Vét. Pays Trop., 53, (3) : 285-292.

47. Youssao, A.K.I., Farougou, S., Koutinhouin, B.G., Bio Bagou, G. and Kora, B.D. (2008) : Aptitudes maternelles de la brebis Djallonké en élevage traditionnel dans la Commune de Banikoara au Bénin, Revue Méd. Vét., 2008, 159, 11, 538-544. 